Historic, Archive Document

Do not assume content reflects current scientific knowledge, policies, or practices. 


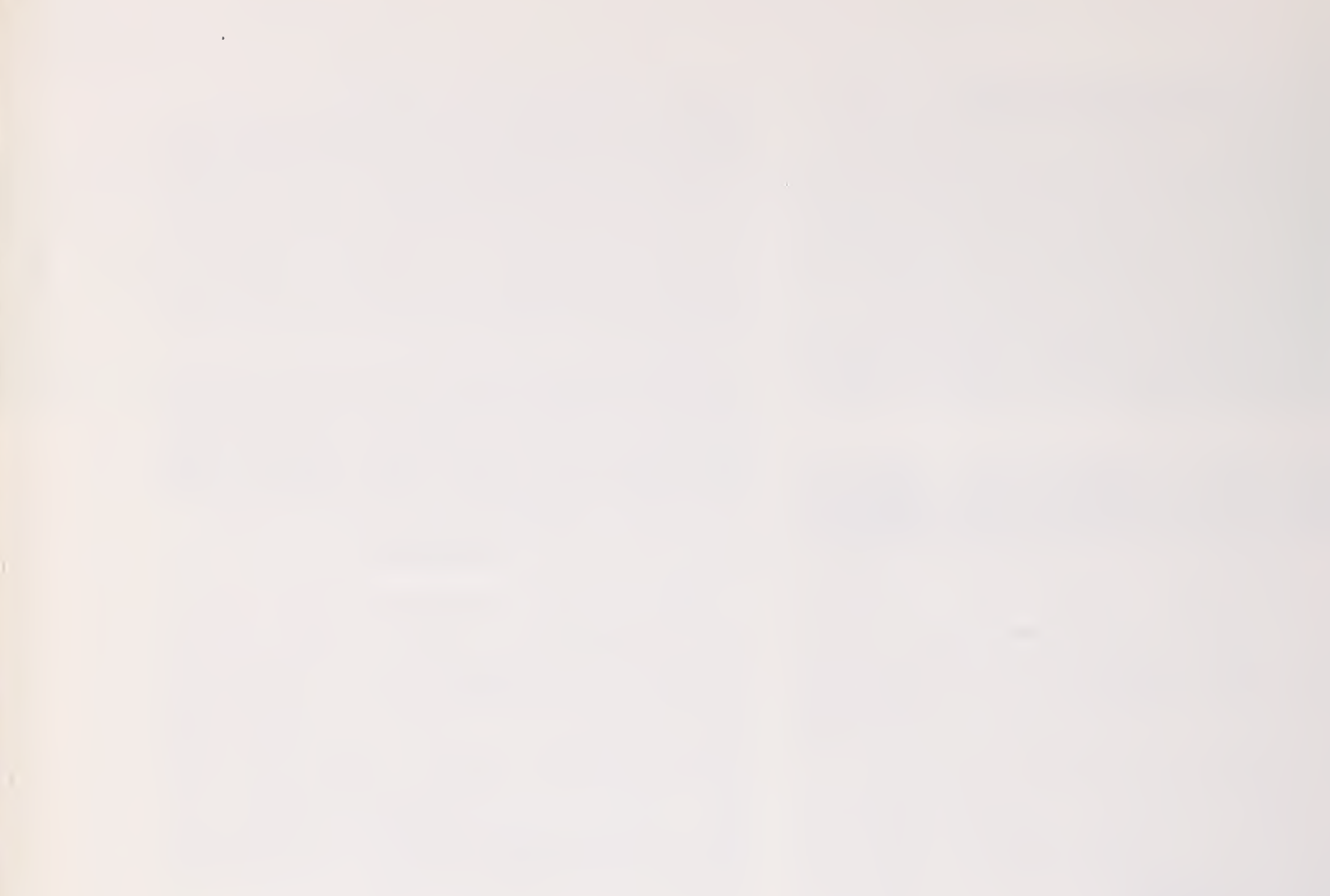




\title{
Phenology and Rate of Height Growth of Some Forbs in the Southwestern Ponderosa Pine Type
}

\author{
Warren P. Clary and William H. Kruse ${ }^{1}$
}

\begin{abstract}
In a 3-year study, two of six primary forb species had possible value as range readiness indicators. Species varied between seasons and sites as available sources of deer forage. Twenty-four secondary forb species showed a diversity of palatable green forage becoming available throughout the growing season.
\end{abstract}

Keywords: Phenology, plant development, deer forbs, southwestern ponderosa pine type.

\section{Management Implications}

Results suggest that the common dandelion may have indicator value for spring "range readiness" of native herbaceous forage. A diversity of green forage is available to deer from mid-spring to early fall in the ponderosa pine vegetation type. The diets of deer reflect this availability: two-thirds of the diet is herbaceous plants (Neff 1974).

Plant development at the Wild Bill Range is 2 weeks later than at the Beaver Creek Watershed. Since the elevation and latitude effects only account for about one-half of this difference, the juxtaposition of a site in relation to major topographic features may be important in predicting phenological development.

\section{Introduction}

Knowledge of herbaceous plant phenology may add to understanding of ecosystem functioning and often has practical applicability. Such know'ledge can be used as a guide to time of "range readiness,"

'Clary is Principal Range Scientist, Intermountain Forest and Range Experiment Station, Provo, Utah. Kruse is Range Technician, Rocky Mountain Forest and Range Experiment Station, Research Work Unit at Flagstaff, in cooperation with Northern Arizona University; Station's headquarters is in Fort Collins in cooperation with Colorado State University. predicting forage quantity and quality, and as an aid in designing grazing systems (Blaisdell 1958, Costello and Price 1939, Jameson 1965). Knowledge of plant phenology is also necessary to effectively time possible herbicide applications.

Forbs often equal or exceed browse in the spring-summer diet of mule deer in north-central Arizona, particularly on treated watersheds (Neff 1974). Since timing, rate, an duration of growth vary greatly among species (Ellison 1954), phenological knowledge of preferred species will provide an additional basis for evaluation of wildlife habitat.

The objective of this study was to provide information on phenology and rate of height growth for a number of forbs in the ponderosa pine type.

\section{Study Areas}

Two study areas, located in north-central Arizona near Flagstaff were used: 5 acres of range unit 2 of the Wild Bill Range (Pearson and Jameson 1967); and 5 acres of watershed 12 on the Beaver Creek Watershed (Brown et al. 1974). These locations were selected primarily because earlier tree removal had allowed numerous herbaceous species to flourish. Timber dominated sites have relatively few herbaceous species at a given location, making a study of this type impractical. 
Both locations are in the ponderosa pine vegetation type, both cleared of timber, and both have volcanic soils. The aspect of both sites is generally southwest, however the slope is nearly level. The Wild Bill Range location (at the western base of the San Francisco Peaks) is 600 feet higher than the Beaver Creek Watershed location, is on the average $3^{\circ}$ to $4^{\circ} \mathrm{F}$ cooler, and receives about $1-1 / 2$ inches less annual precipitation (table 1).

The Wild Bill Range is a pure stand of ponderosa pine (Pinus ponderosa Laws.) (nomenclature follows McDougall 1973) with a herbaceous understory dominated by Arizona fescue (Festuca arizonica Vasey) and mountain muhly (Muhlenbergia montana (Nutt.) Hitchc.). The forest stand at Beaver Creek is approximately $85 \%$ ponderosa pine and 15\% Gambel oak (Quercus gambelii Nutt.) and alligator juniper (Juniperus deppeana Steud.). The understory is dominated by mutton grass (Poa fendleriana (Steud.) Vasey), bottlebrush squirreltail (Sitanion longifolium J.G. Smith), and blue grama (Bouteloua gracilis (H.B.K.) Lag.).

\section{Methods}

Five species were selected at each location for intensive height measurements. These species represented a variety of growth habits and were the primary species studied. Four species, houstonia (Houstonia wrightii Gray), dandelion (Taraxacum officinale Weber), fleabane (Erigeron divergens Torr. and Gray), and wormwood (Artemisia carruthii Wood) were studied on both areas. Showy aster (Aster commutatus Torr. and Gray) was the fifth species studied at the Beaver Creek Watershed, while conyza (Conyza schiedeana (Less.) Cronquist) was the fifth species at the Wild Bill Range. Fifteen individual plants of each species were randomly staked and tagged. This number was sufficient to sample a species height on a given date within a standard error of approximately $12 \%$ of the sample mean. Height to the nearest $1 / 2$ inch and phenologic stage were recorded at 2 -week intervals throughout three growing seasons. On each 2-week measurement date, the typical phenologic stage was recorded on 24 other forb species and two grass species.

A multivariate profile analysis for differences in average height growth among primary species and dates and their interaction was made using a computer program titled, "Analysis of growth data with repeated measurements."

\section{Results and Discussion}

\section{Primary Species}

The statistical tests of height growth among species, dates, and species $\mathrm{x}$ dates were all highly significant for each of the 3 years of measurement. Heights also varied between the two study areas (figs. 2 through 6). In general, the taller species showed the most variation, while the prostrate species showed the least. Figure 1 illustrates the height and form of the primary species.

Measurements and observations in this study suggest different values and uses for different species. Prostrate plants, such as houstonia (which is inconspicuous and relatively uniform in height), have little value as phenological indicators; however, they may serve as a reliable source of deer forage (Neff 1974), particularly in dry years, because of their consistent year-to-year response (fig. 2). Another prostrate species, dandelion, may have indicator value. The showy yellow blossoms of this

Table 1.-Long term and monthly precipitation and temperature averages for each study location

\begin{tabular}{|c|c|c|c|c|c|c|}
\hline \multicolumn{7}{|c|}{ Precipitation (inches) } \\
\hline & \multicolumn{3}{|c|}{ Wild Bill Range } & \multicolumn{3}{|c|}{ Beaver Creek Watershed } \\
\hline & Winter ${ }^{1}$ & Summer & Total & Winter & Summer & Total \\
\hline Long Term & 11.24 & 10.10 & 21.34 & 13.01 & 9.79 & 22.80 \\
\hline $1970-71$ & 5.02 & 11.05 & 16.07 & 6.21 & 12.59 & 18.80 \\
\hline $1971-72$ & 6.98 & 10.10 & 17.08 & 8.67 & 9.61 & 18.28 \\
\hline $1972-73$ & 26.14 & 7.61 & 33.75 & 29.71 & 5.09 & 34.80 \\
\hline
\end{tabular}

Temperature $\left({ }^{\circ} \mathrm{F}\right)$

\begin{tabular}{|c|c|c|c|c|c|c|}
\hline & \multicolumn{3}{|c|}{ Wild Bill Range } & \multicolumn{3}{|c|}{ Beaver Creek Watershed } \\
\hline & Winter & Summer & Avg. & Winter & Summer & Avg. \\
\hline Long Term & 31.0 & 52.3 & 41.7 & 34.3 & 56.2 & 45.2 \\
\hline $1971-72$ & 31.0 & 51.2 & 41.1 & 33.5 & 54.7 & 44.1 \\
\hline $1972-73$ & 25.5 & 50.2 & 37.8 & 30.0 & 54.0 & 42.0 \\
\hline
\end{tabular}

'Winter = October through March; Summer = April through September 


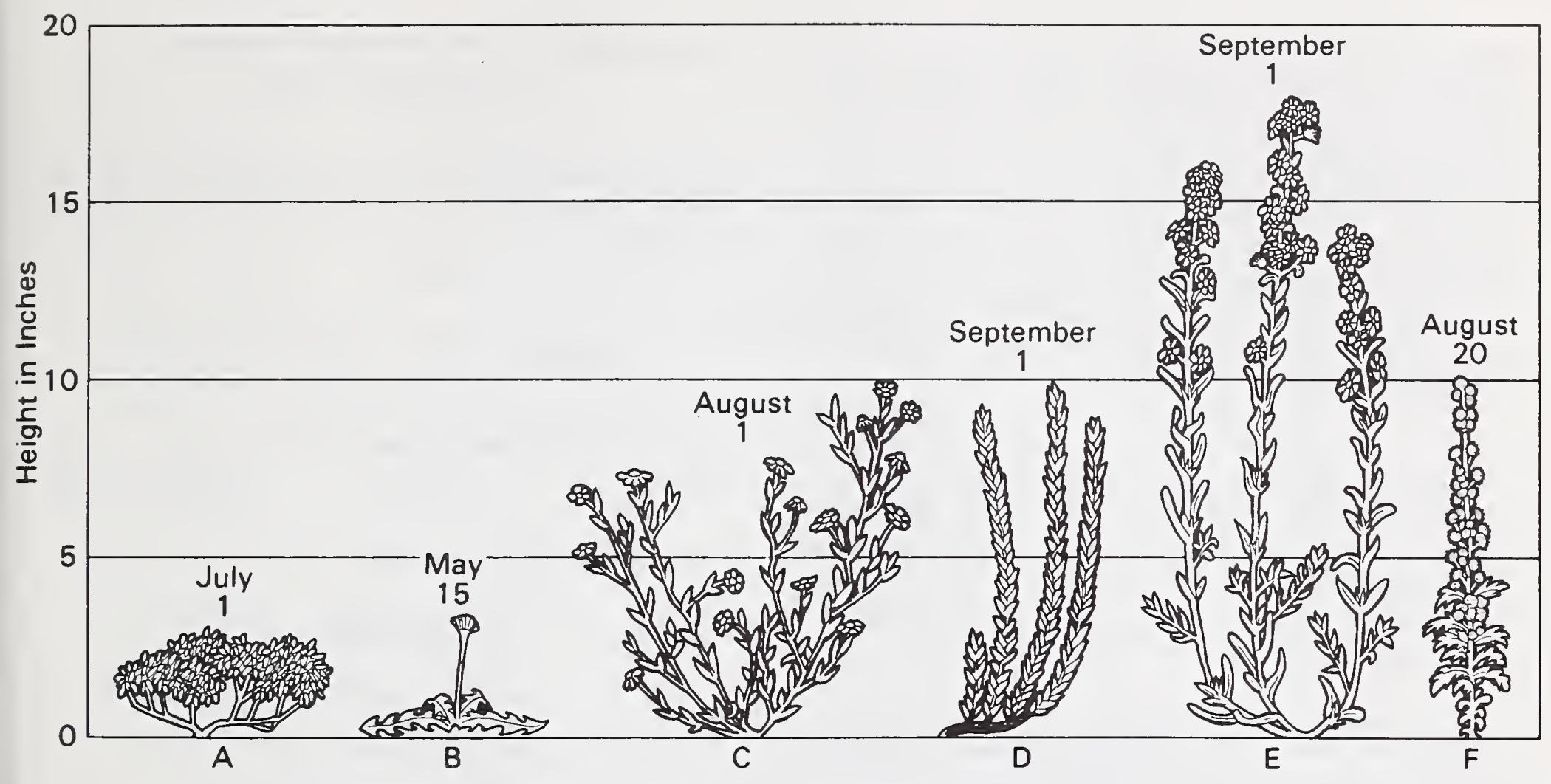

Figure 1. - Illustration of the six primary species showing their height at full bloom (average 3 years): (A) houstonia; (B) common dandelion; (C) fleabane; (D) wormwood; (E) showy aster, and $(F)$ conyza.

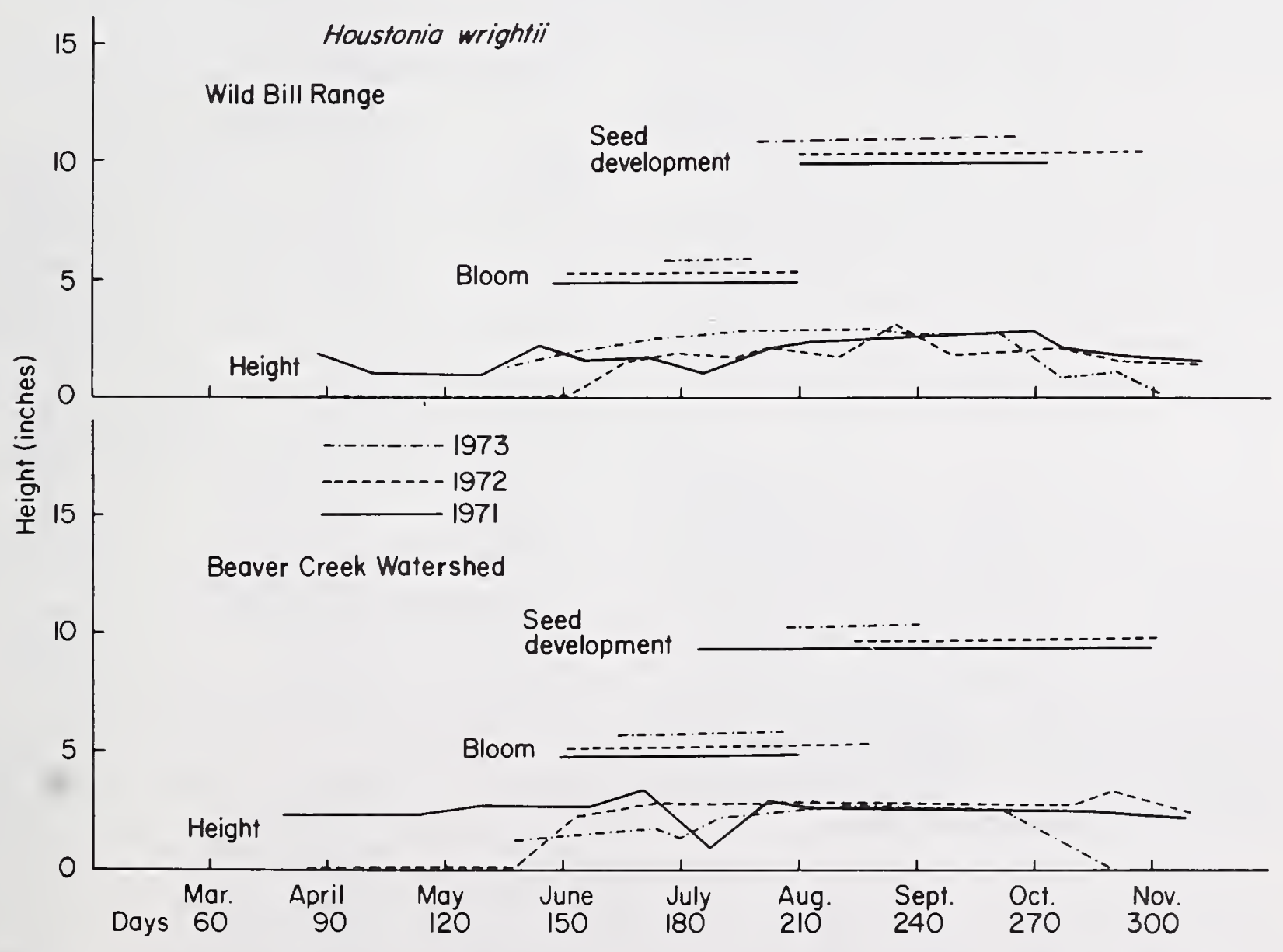

Figure 2.-Height and stage of development for Houstonia wrightii at the Wild Bill Range and at the Beaver Creek Watershed. 
plant are well known, and their presence may be a signal of "range readiness." For instance, the absence of flowers on May 1 may suggest a late spring and therefore beginning dates for grazing should possibly be set back. The indicator value of dandelion is restricted to early and mid-spring use because this plant is strongly limited by long photoperiods (Solbrig 1971), causing flowering to terminate abruptly in late spring (fig. 3). Further studies of the use of dandelion as an indicator should be conducted under a variety of conditions.

The vegetative growth of spreading fleabane is one of the most responsive to differences in years of any of the plants studied (fig. 4). This abundant plant is an important wildlife food, readily eaten by deer (Neff 1974). However, its availability may be late in some years, as in 1971 when it did not appear until after August 1 at the Wild Bill Range.

Two species which develop late in the growing season, wormwood (measured at both sites) and showy aster (measured at Beaver Creek Watershed only), appear to be little affected by spring weather conditions (figs. 5 and 6). The main year-to-year differences are responses in vegetative growth to summer precipitation. The aster is quite showy when in bloom and palatable to both livestock and wildlife. It often makes up more than $50 \%$ of the production of preferred deer forage in dry summers when many summer annuals fail to appear. ${ }^{2}$

The last species for which growth measurements were taken, conyza (at the Wild Bill Range only), failed to appear in 1973 under conditions of a cool wet spring and a dry summer (fig. 6). This plant appeared to be grazed by both cattle and deer or elk, but it is probably of limited value as a phenologic indicator unless perhaps considered on a presence or absence basis.

The very high total precipitation during measurement year 1972-73 had little obvious beneficial effect on the plants studied. Up to $85 \%$ of the precipitation came during October through March. The resulting deep snow cover delayed initial plant growth, although once begun growth followed a relatively normal early summer pattern. A deficiency in mid and late summer precipitation apparently resulted in less total height growth in 1973 for most species than for the other 2 measurement years.

'Unpublished data, Beaver Creek Watershed

\section{Other Species and the Availability of Green Forb Forage}

Twenty-four other species were observed and the typical phenologic stage recorded on each observation date:

Scientific names of other forb species (nomenclature follows McDougall 1973)

\begin{tabular}{|c|c|c|}
\hline Symbol & $\begin{array}{c}\text { Scientific name and } \\
\text { authority }\end{array}$ & Common name \\
\hline ACLA & $\begin{array}{l}\text { Achillea lanulosa } \\
\text { Nutı. }\end{array}$ & Western yarrow \\
\hline AN PA & $\begin{array}{l}\text { Antennaria parvifolia } \\
\text { Nutt. (A. aprica } \\
\text { Greene) }\end{array}$ & Pussy toes \\
\hline ASTE & $\begin{array}{l}\text { Astragalus tephrodes } \\
\text { Gray. }\end{array}$ & Milk vetch \\
\hline BADI & $\begin{array}{l}\text { Bahia dissecta (Gray) } \\
\text { Britton. }\end{array}$ & Bahia \\
\hline CIWH & $\begin{array}{l}\text { Cirsium wheeleri } \\
\text { (Gray) Petrak. }\end{array}$ & Thistle \\
\hline DAAL & Dalea albiflora Gray. & $\begin{array}{l}\text { Indigobush; } \\
\text { paa bush }\end{array}$ \\
\hline DECO & $\begin{array}{l}\text { Desmanthus cooleyi } \\
\text { (Eaton) Trel. }\end{array}$ & Desmanthus \\
\hline EPPA & $\begin{array}{l}\text { Epilobium pani- } \\
\text { culatum Nutt. }\end{array}$ & Willow weed \\
\hline ERUM & $\begin{array}{l}\text { Eriogonum um- } \\
\text { bellatum Torr. } \\
\text { (E. cognatum } \\
\text { Greene.) }\end{array}$ & $\begin{array}{l}\text { Wild buck- } \\
\text { wheat }\end{array}$ \\
\hline ERFL & $\begin{array}{l}\text { Erigeron flagellaris } \\
\text { Gray. }\end{array}$ & $\begin{array}{l}\text { Spreading flea } \\
\text { bane }\end{array}$ \\
\hline ERFO & $\begin{array}{l}\text { Erigeron formosis- } \\
\text { simus Greene. }\end{array}$ & $\begin{array}{l}\text { Fleabane, wild } \\
\text { daisy }\end{array}$ \\
\hline ERRA & $\begin{array}{l}\text { Eriogonum race- } \\
\text { mosum Nutt. }\end{array}$ & $\begin{array}{l}\text { Wild buck- } \\
\text { wheat }\end{array}$ \\
\hline FEAR & $\begin{array}{l}\text { Festuca arizonica } \\
\text { V'asey. }\end{array}$ & Arizona fescue \\
\hline GEFR & $\begin{array}{l}\text { Geranium fremontii } \\
\text { Torr. }\end{array}$ & Cranesbill \\
\hline GIMU & Gilia multiflora Nutt. & Gilia \\
\hline HYLU & $\begin{array}{l}\text { Hymenopappus } \\
\text { lugens Greene. }\end{array}$ & White-ragweed \\
\hline LASE & Lactuca serriola $\mathrm{L}$. & Wild lettuce \\
\hline LOWR & $\begin{array}{l}\text { Lotus wrightii } \\
\text { (Gray) Greene. }\end{array}$ & Deer vetch \\
\hline MEOF & $\begin{array}{l}\text { Melilotus officinalis } \\
\text { (L.) Lam. }\end{array}$ & $\begin{array}{l}\text { Yellow sweet- } \\
\text { clover }\end{array}$ \\
\hline PHWO & $\begin{array}{l}\text { Phlox woodhousei } \\
\text { (Gray) Nels. }\end{array}$ & Phlox \\
\hline POAV & $\begin{array}{l}\text { Polygonum ariculare } \\
\text { L. }\end{array}$ & $\begin{array}{l}\text { Knotweed, } \\
\text { smartweed }\end{array}$ \\
\hline SILO & $\begin{array}{l}\text { Sitanion longifolium } \\
\text { J.G. Smith }\end{array}$ & $\begin{array}{l}\text { Bottlebrush } \\
\text { squirreltail }\end{array}$ \\
\hline SOMI & $\begin{array}{l}\text { Solidago missouriensis } \\
\text { Nutt. }\end{array}$ & Goldenrod \\
\hline TRDU & $\begin{array}{l}\text { Tragopogon dubius } \\
\text { Scop. }\end{array}$ & Goatsbeard \\
\hline VETH & Verbascum thapsus L. & Mullein \\
\hline
\end{tabular}




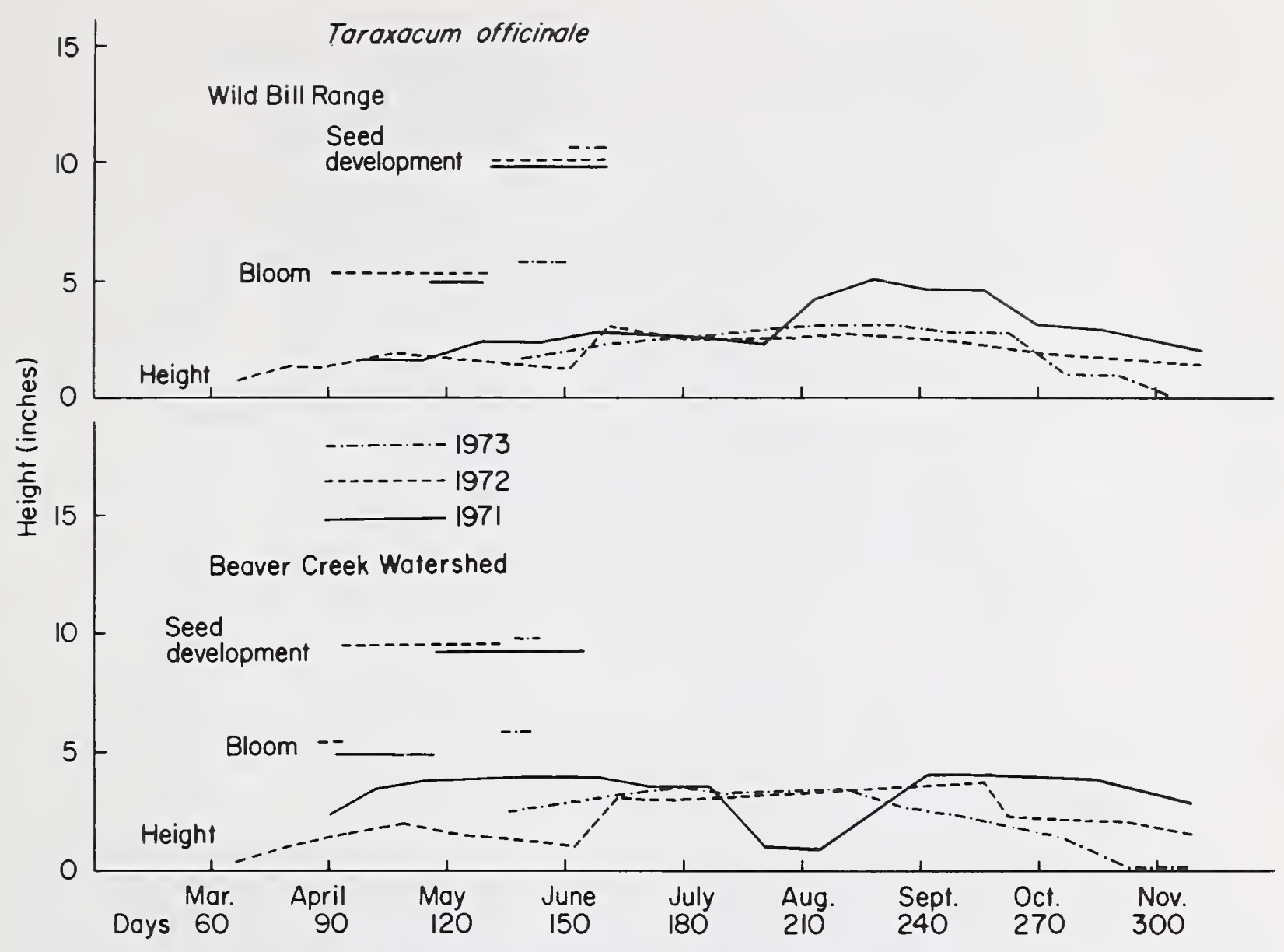

Figure 3.-Height and stage of development for Taraxacum officinale at the Wild Bill Range and at the Beaver Creek Watershed.

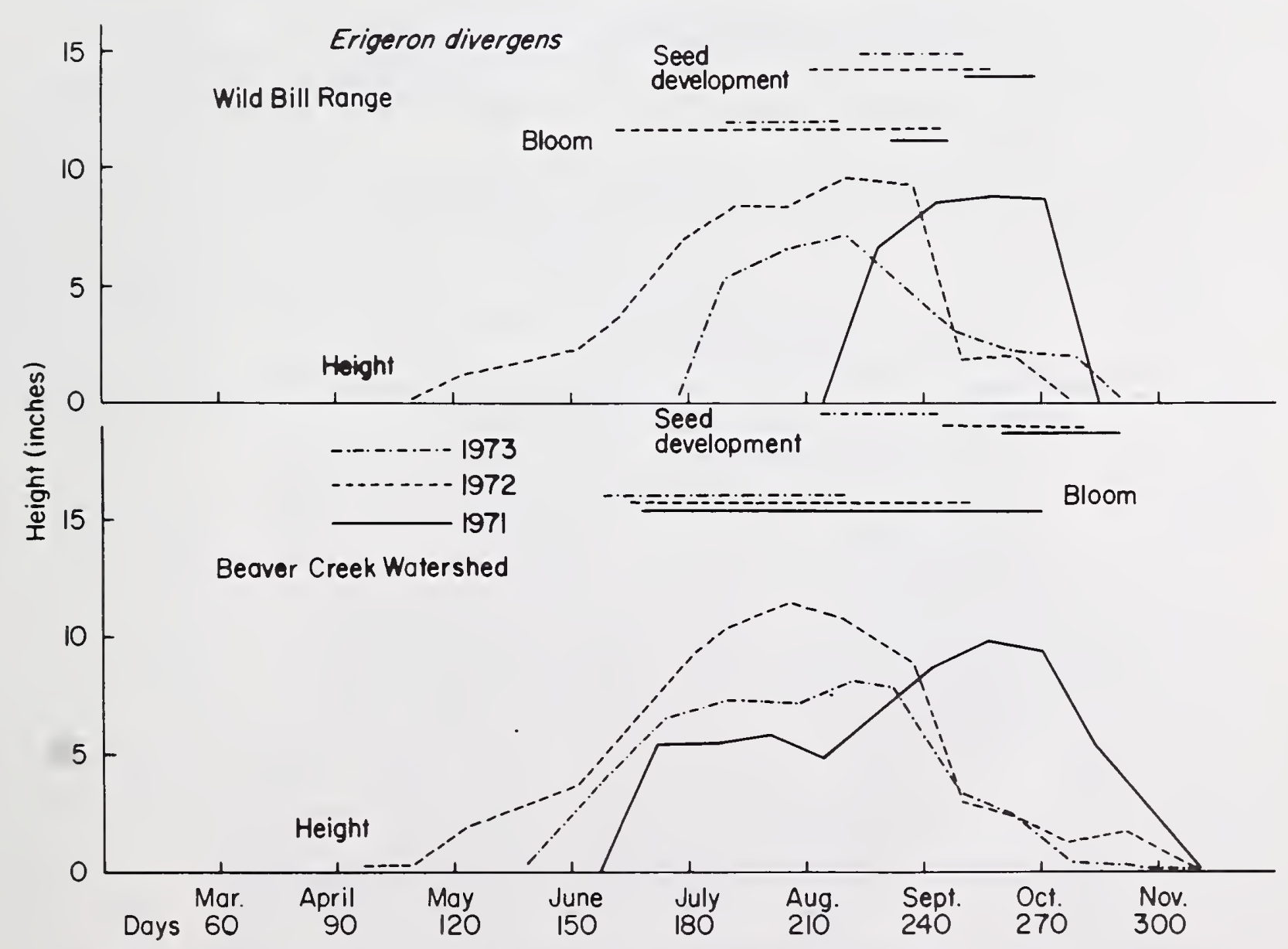

Figure 4.-Height and stage of development for Erigeron divergens at the Wild Bill Range and at the Beaver Creek Watershed. 


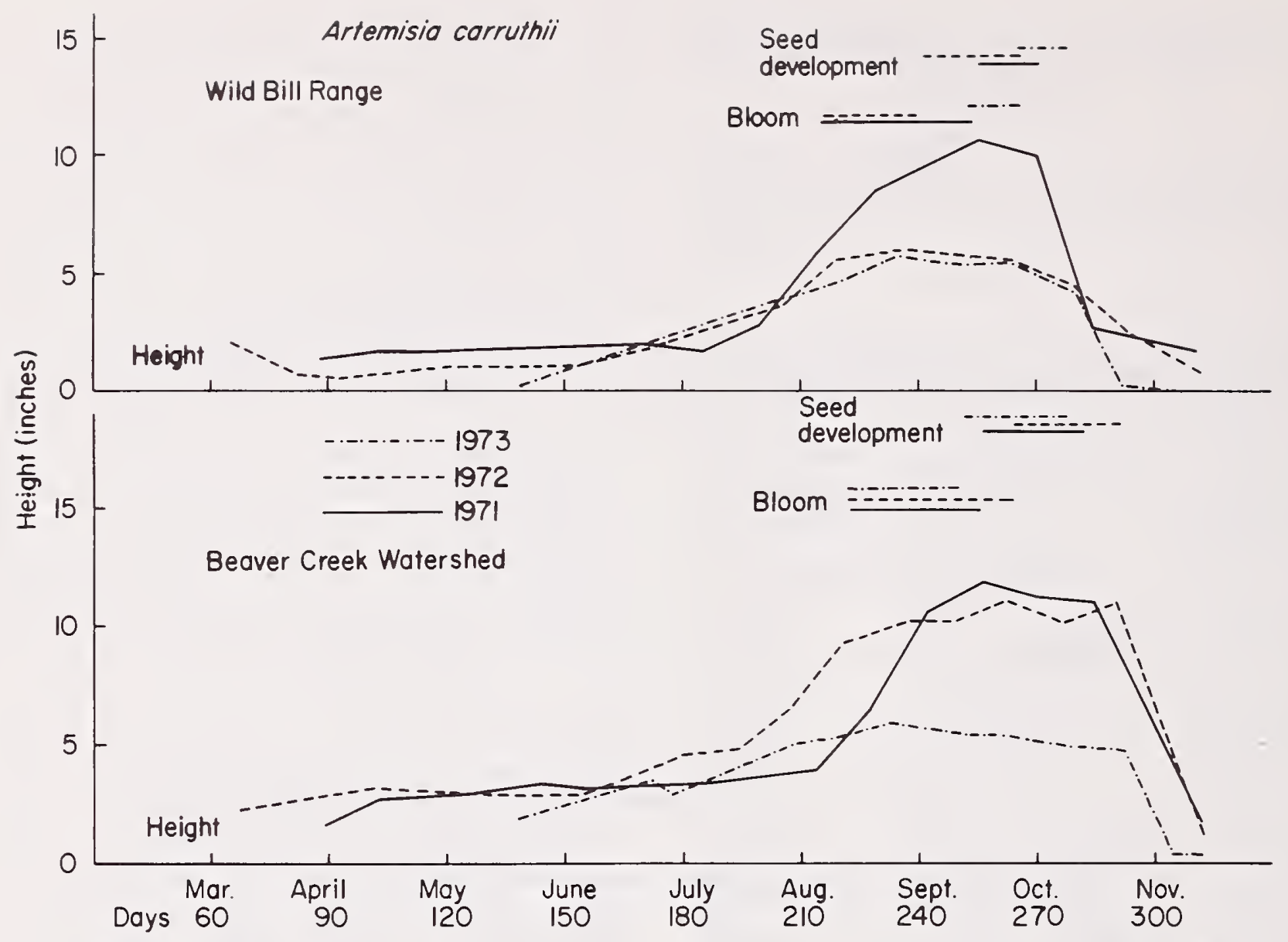

Figure 5.-Height and stage of development for Artemisia carruthii at the Wild Bill Range and at the Beaver Creek Watershed.

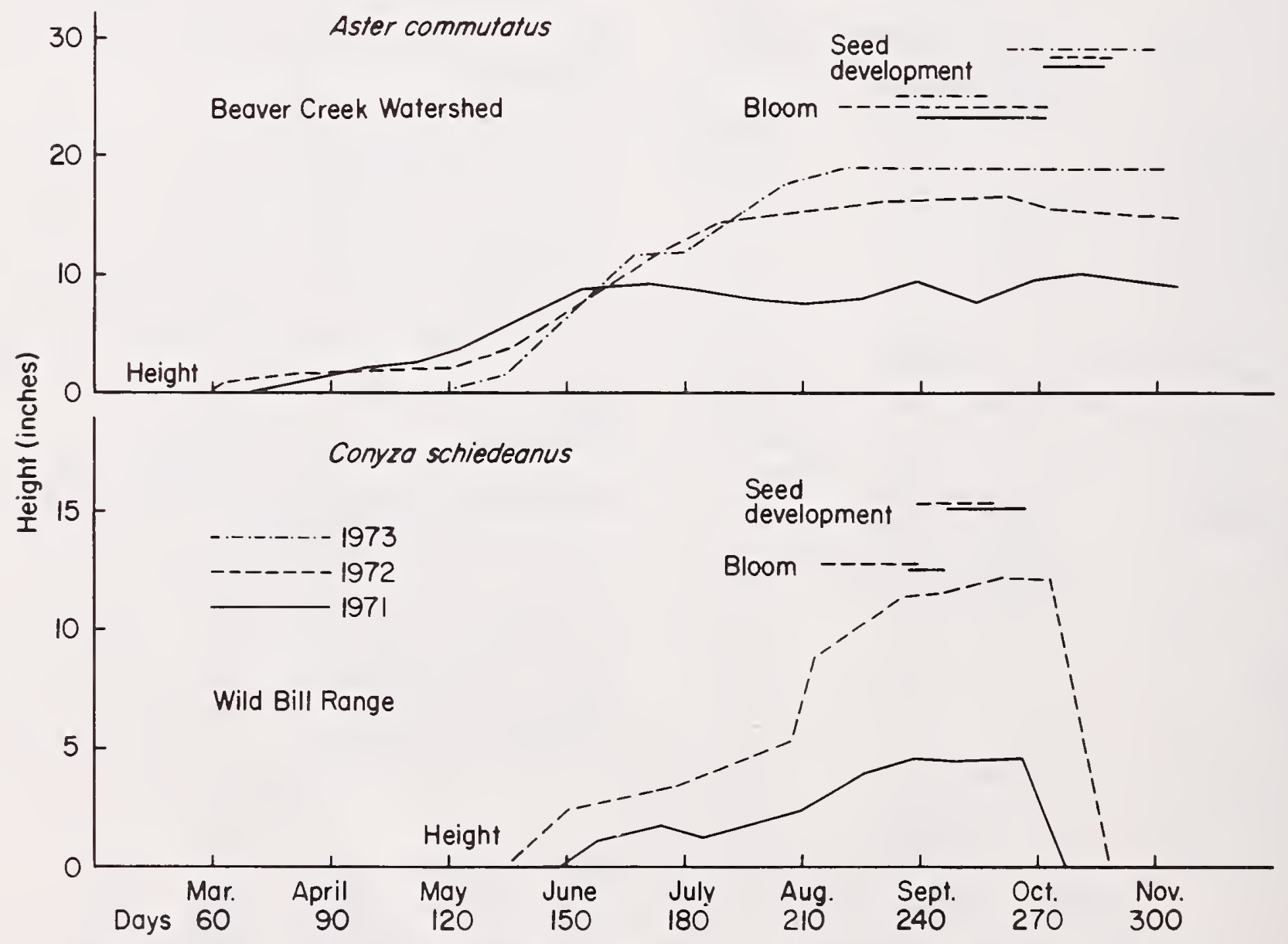

Figure 6.- Height and stage of development for Aster commutatus at the Beaver Creek Watershed and Conyza schiedeanus at the Wild Bill Range. 


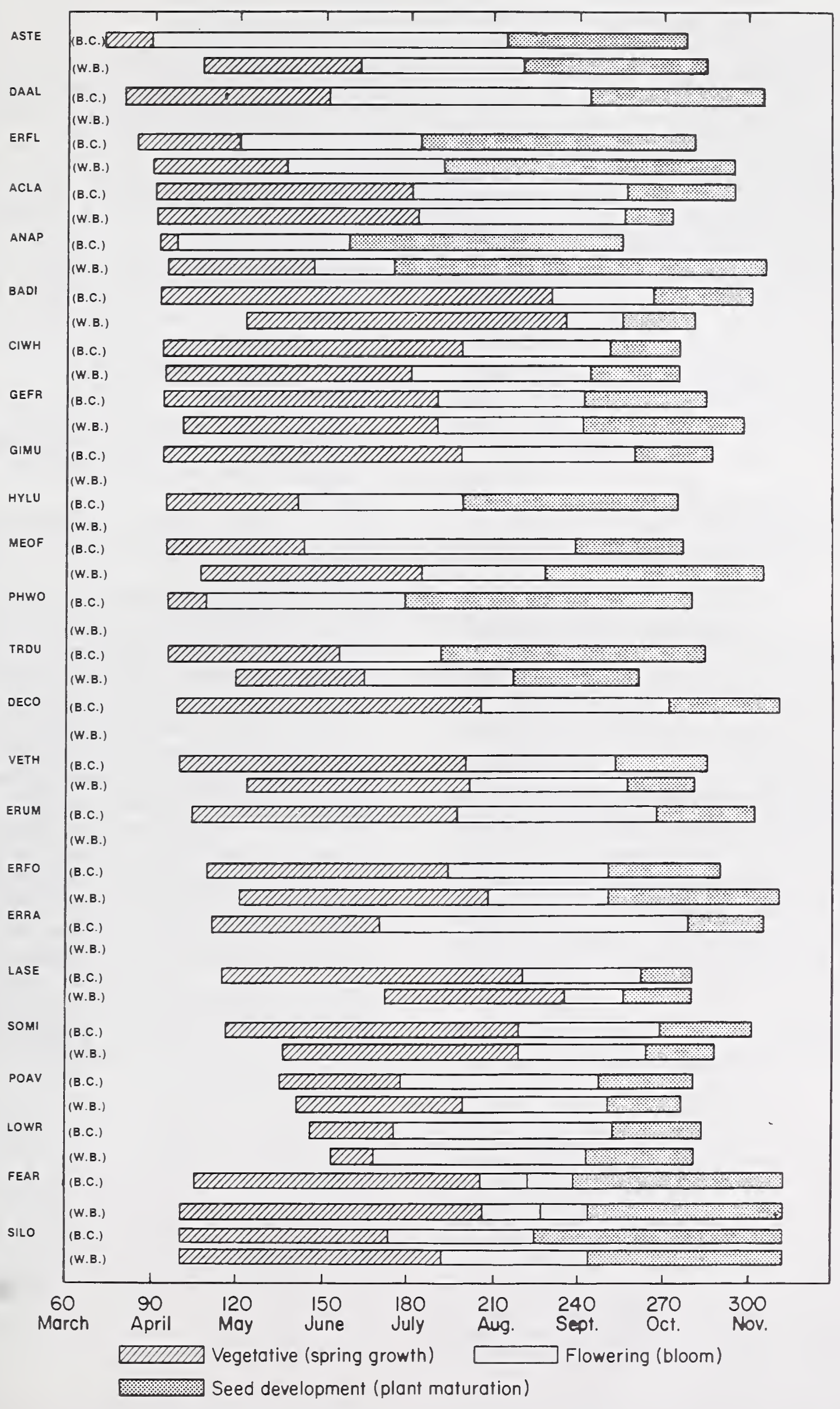

Figure 7.- Phenology of minor forbs at the Wild Bill Range (W.B.) and at the Beaver Creek Watershed (B.C.) (average of 3 years). 
Knowledge of species phenology provides information on timing of forage availability and, by inference, something of the type of forage available (e.g., rosettes, leafage, and flower stalks).

A visual comparison of broad growth stages is shown in figure 7 . The figure represents an average of 3 years. A sequence of new growth started over a 6week period at both locations. In general, growth started 2 weeks later at the Wild Bill Range than at the Beaver Creek Watershed. Plants in which growth initiation varied the most between areas were goatsbeard (20 days), Missouri goldenrod (18 days), and bahia (20 days). Even greater differences occurred between areas in blooming dates of some species. Those with the greatest differences include pussytoes (47 days), milk vetch (74 days), yellow sweetclover (40 days) and knotweed (2l days).

The plant development stages illustrate a diversity of green forage palatable to deer (Neff 1974) was available throughout the growing season at both study areas.

Plant development was about 2 weeks later at the Wild Bill Range than at Beaver Creek Watershed, a much greater difference than would be expected from the elevation difference of only 600 feet. The expected difference based on Hopkins' Bioclimatic Law (Hopkins 1918) and calculated from elevation and latitude would be only 8 days, or about one-half the actual difference. The difference in mean temperature of $3.5^{\circ} \mathrm{F}$ is also greater than would be expected and accounts for a portion of the phenological variation between the two areas. Locations influenced by the presence of large mountains and other unknown factors may experience climatic variations accompanied by plant phenology differences, which are not directly predictable from other areas of similar elevation.

\section{Literature Cited}

Blaisdell, James P. 1958. Seasonal development and yield of native plants on the upper Smoke river plains and their relation to certain climatic factors. USDA Tech. Bull. 1190, 68 p. Washington, D.C.

Brown, Harry E., Malchus B. Baker, Jr., James J. Rogers, Warren P. Clary, J. L. Kovner, Frederic R. Larson, Charles C. Avery, and Ralph E. Campbell. 1974. Opportunities for increasing water yields and other multiple use values on ponderosa pine forest lands. USDA For. Serv. Res. Pap. RM-129, 36 p. Rocky Mt. For. and Range Exp. Stn., Fort Collins, Colo.

Costello, David F., and Raymond Price. 1939. Weather and plant-development data as determinants of grazing periods on mountain range. USDA Tech. Bull. 686, 30 p. Washington, D.C.

Ellison, Lincoln. 1954. Subalpine vegetation of the Wasatch Plateau, Utah. Ecol. Monogr. 24:89-184.

Hopkins, A. D. 1918. Periodical events and natural law as guides to agricultural research and practice. U.S. Mon. Weather Rev. Suppl. 9:5-42.

Jameson, Donald A. 1965. Phenology of grasses of the northern Arizona pinyon-juniper type. USDA For. Serv. Res. Note RM-47, 8 p. Rocky Mt. For. and Range Exp. Stn., Fort Collins, Colo.

McDougall, Walter B. 1973. Seed plants of northern Arizona. 593 p. Museum North. Ariz., Flagstaff.

Neff, Don J. 1974. Forage preferences of trained mule deer on the Beaver Creek Watersheds. Ariz. Game and Fish Dep. Spec. Rep. 4, 61 p. Phoenix.

Pearson, Henry A., and Donald A. Jameson. 1967. Relationship between timber and cattle production on ponderosa pine range: The Wild Bill Range. 10 p. U.S. Dep. Agric., For. Serv., Rocky Mt. For. and Range Exp. Stn., Fort Collins, Colo.

Solbrig, Otto T. 1971. The population biology of dandelions. Am. Sci. 59:686-694. 